\title{
A Comparison Between The Concept Of Meditation In Buddhism And Mur $_{7}$ Qabah In Islam
}

\section{* Dr. Souaad Muhammad Abbas}

\begin{abstract}
Mysticism and the spiritual experiences that lie in mysticism in different world religions have always fascinated me, and a source of attraction to me. With regards to Islam and Buddhism, I believe that devotion to religious morals and duties is the key to reach contentment in life.

Meditation is a vital component of almost all the religions whether revealed or nonrevealed. It is a mental and a physical discipline by which the meditator strives to reach beyond the material world into the realm of the spiritual and divine world. Different religions adopt different forms of meditational techniques that emphasize on different goals. It can be union with the absolute as in Hinduism. Or it can be getting close to Allah as in Islam or to reach a highest bliss that lies beyond the mortal world that is Nirvana ${ }^{\mathrm{i}}$ in Buddhism, etc. It is also practiced outside the religious tradition for simply soothing and calming the mind. Many people practice meditation as a way to improve one's mental, spiritual and also physical health. Whatever goals are sought through meditation, it is quite evident that meditation is related to spirituality and spirituality is a basic part of religion. In this article I have discussed some of the major concepts in the spiritual journey of meditation in both the disciplines and compared between them.
\end{abstract}

Keywords : Spiritual, Islam, Buddhism,Meditation, Mutraqabah

\section{* Lecturer, Department of Islamic Studies, NUML, Islamabad.}




\section{Definition of meditation in Buddhism and Islam:}

\section{Definition of meditation in Buddhism:}

The English word meditation does not absolutely translate any single term or concept in Buddhism; rather it is used to translate several words in $\mathrm{P}_{\rceil}$li and Sanskrit. There are three basic terms in Buddhism that are used for meditation.

$J h_{\rceil} n a$ (Sanskrit $d h_{ך} n a$ ), $S a m_{\rceil} d h i$ and $B h_{\rceil} v a n_{\rceil}$. The definition of each of them is given below:

\section{$\mathrm{Jh}_{\rceil}$na: (trance):}

It is "A state of serene contemplation attained by meditation". ii

$\mathrm{Jh}_{\rceil}$na is the $\mathrm{P}_{\rceil}$li term meaning "trance," "absorption," or "meditation."

The Sanskrit equivalent is $\mathrm{Dh}_{\rceil}$na. To experience $\mathrm{Jh}_{\rceil}$na means to get along the four meditative states in the Buddhist tradition that leads to the ultimate bliss "nirvana".

The four states of $\mathrm{Jh}_{\rceil}$na are taught to all those who practice Buddhist meditation.

In order to attain $\mathrm{Jh}_{\rceil}$na, five hindrances must be overcome, namely: sensory desires, ill will, indolence, restlessness and worry and distrustful doubts. To overcome the five hindrances the meditator has to rise above the five factors of $\mathrm{Jh}_{7}$ na namely onepointedness of mind, zest, right thinking, happiness and investigation. When these factors are left behind, $\mathrm{Jh}_{\rceil}$na is obtained in a fuller sense. ${ }^{\text {iii }}$

The state of $\mathrm{Jh}_{\rceil}$na is not an end in itself but leads to further progress, as in the case of Buddha who went on from $\mathrm{Jh}_{\rceil}$na to nirv $\urcorner$Fa.

\section{Dhy $_{\urcorner}$na: $\left(P_{\urcorner}\right.$li: $J_{\urcorner}$na):}

It is a Sanskrit term that means "meditation", which is important in the Jain, Hindu and Buddhist traditions. ${ }^{\text {iv }}$ The word chan ${ }^{\mathbf{v}}$ in Chinese Buddhism and the word zen ${ }^{\text {vi }}$ in Japanese Buddhism are derived from the word $\mathrm{dhy}_{7}$ na; it is a general designation for meditation which is of central significance in Buddhism.

It is "a state of abstract meditation inculcated upon Buddhist ascetics, and which they believe leads to the entire destruction of all cleaving to existence". vii

\section{$\mathrm{Sam}_{\rceil}$dhi:}

$\mathrm{Sam}_{\rceil}$dhi literally means "mental discipline". It means to be in a state of bliss and to have a focused concentration. ${ }^{\text {vii }}$ 
In Buddha's discourse sam 7 dhi is also one of the components of the noble eight fold path that contains right effort ${ }^{\mathrm{ix}}$, right mindfulness ${ }^{\mathrm{x}}$ and right concentration $\left(\mathrm{sam}_{7} \mathrm{dhi}\right)^{\mathrm{xi}}$

\section{$B h_{\rceil}$van:}

$\mathrm{Bh}_{\rceil} \operatorname{van}_{\rceil}$is a Sanskrit terminology which means "dwelling," and then, "it evolved to refer to meditation". xii

There are two main types of Buddhist $\mathrm{bh}_{\rceil} \mathrm{van}_{\rceil}: \mathrm{Sam}_{\rceil} \mathrm{dhi}_{\mathrm{bh}} \mathrm{van}_{\rceil}$and Vipassan ${ }$xiii $\mathrm{bh}_{\rceil} \mathrm{van}_{\rceil} . \mathrm{Sam}_{\rceil}$dhi $\mathrm{bh}_{\rceil} \mathrm{van}_{\rceil}$also known as the development of concentration or tranquility meditation, and the latter Vipassan $\mathrm{bh}_{\rceil} \mathrm{van}_{\rceil}$also known as the development of wisdom (paññ $)$ ) or the meditation of insight. The utmost aim to practice Sam $\mathrm{S}_{\rceil}$dhi meditation is to develop a calm, concentrated and a cohesive mind to experience the inner peace and that will form the basis for wisdom. On the other hand the utmost aim to practice insight meditation is to gain a true understanding of the real and true nature of every phenomenon that is free of delusions and misapprehensions.

Of the two, the practice and the development of insight meditation is regarded in Buddhism as the essential key to liberation and salvation, whereas $\mathrm{Sam}_{7}$ dhi meditation helps at developing concentration necessary for insight meditation.

\section{Definition of al-Mur qabah in Islam:}

\section{Literal definition of al-Mur qabah in Islam:}

Like many other faith communities, meditation is also practiced in Islam and is known as Murך qabah.

\section{Mur $q$ qabah Literally}

I have quoted some of the literal meanings of mur $q$ qabah given by a few renowned linguists.

\section{Ibn Man $\sqcup^{-} \perp_{\mathrm{r}}$ definition in $L i s_{\rceil} \boldsymbol{n}$ al-'Arab:}

The word mur $q a b a h$ is derived from the root word (r.q.b.); that is one of the ninety nine

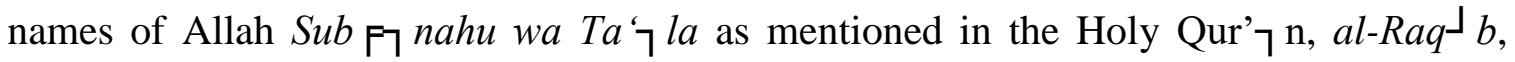
which means "the Vigilant" who watches over everything and nothing is hidden from his knowledge. ${ }^{\text {iiv }}$

According to Ibn Man $\left\llcorner\perp_{\mathrm{r}}\right.$ one of the meanings of r.q.b. is to take care and safeguard as in

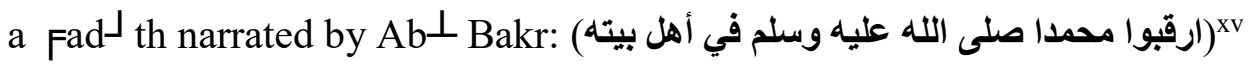


In this $\mathrm{Fad}^{\lrcorner}$th r.q.b. means: to consider and safeguard. ${ }^{\mathrm{xvi}}$

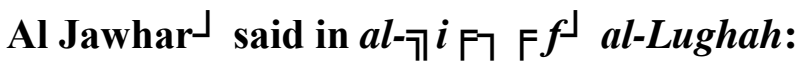

$A l-R a q\lrcorner b$ the keeper and saviour, r.q.b. also means "to wait".

means to fear Allah Sub Fך nahu wa Ta ךla in every matter and to be aware

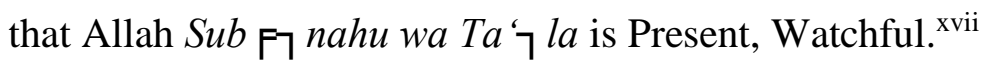

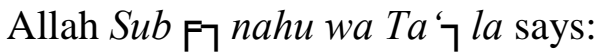

"O mankind! Fear your God Who created you from one soul and made its wife from within it, and from that pair God created many men and women and fear Allah in Whose name you demand and ask for (your rights) and do not cut your relationships. Surely, Allah is All Watcher over you". xviii

It means that Allah $S_{\mathrm{Su}} \mathrm{F} n a h u$ wa $T a{ }_{\uparrow} l a$ watches over everything and that through mur qabah, a person watches over and takes care of his each and every act and that he is sure of the Divine Presence, which is ever vigilant. ${ }^{\text {xix }}$

\section{Al-Azhar ${ }^{\lrcorner}$said in his book Tahdh ${ }^{\lrcorner}$b al-Lughah}

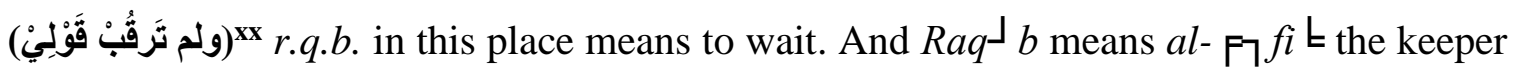
and saviour. ${ }^{\mathrm{xxi}}$

R.q.b. also means to observe, guard or control one's thoughts and desires. ${ }^{\text {xxii }}$

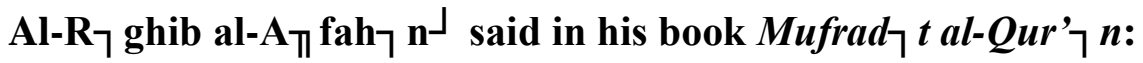

R.q.b. according to $\mathrm{Al}-\mathrm{R}_{\rceil}$ghib al- $\mathrm{A}_{\rceil} \mathrm{fah}_{\eta} \mathrm{n}^{\lrcorner}$means to watch and $\left.A l-R a q\right\lrcorner b$ means the Watcher as mentioned in the Holy $\left.Q u r^{\prime}\right\urcorner n$ "So watch; indeed, I am with you a watcher, [awaiting the outcome]." xxiii $A l-R a q\lrcorner b$ also means $a l-\sqcap{ }^{f i}{ }^{\text {Lxiv }}$ (the saviour).

If we reflect and consider the texts mentioned above we can conclude the following meanings of r.q.b.:

1- To observe and watch over

2- To wait and consider

3- To take care and safeguard

\section{Mur qabah Technically:}

1. Knowledge and certainty of the servant of Allah Sub $\mathrm{F}_{7}$ nahu wa Ta $\mathrm{T}_{\mathrm{l}} \mathrm{la}$

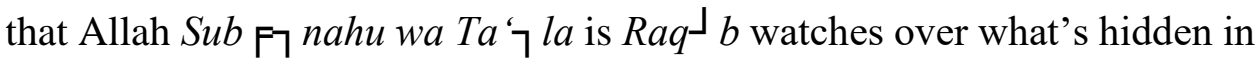
his heart and conscious, hence governs his conduct by this knowledge. ${ }^{\mathrm{xxv}}$ 
2. Imam Qushair」 said, "mur $q a b a h$ is to be always conscious of Allah $S u b F_{\uparrow}$ nahu wa $T a$ ‘ la's presence and His vigilance over everything and to regulate ones deeds (accordingly). ${ }^{\mathrm{xxvi}}$

3. The servant's knowledge, his conviction and certainty that Allah Sub $\mathrm{F}^{n}$ nahu wa Ta ${ }_{\uparrow} l a$ is watching over his internal and external affairs. $^{\text {xxvii }}$

All the definitions denote the same meaning that one should have mur qabah for Allah

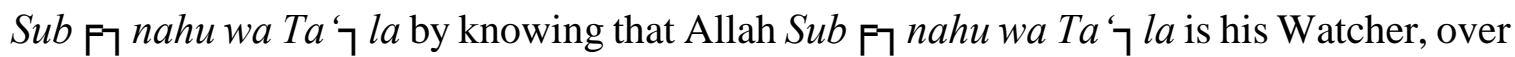
Seeing him, Hearing his utterances, and Observing all of his deeds at all times. The fruit of

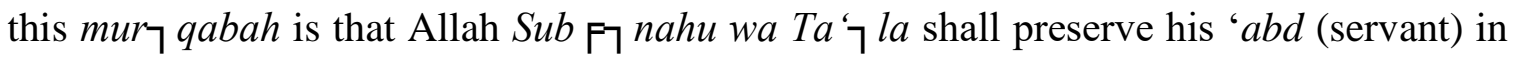
all his actions internally and externally.

According to my understanding the practice of mur 7 qabah is not confined to a specific area of worship in Islam e.g: dhikr (remembrance of Allah Sub $\mathrm{F}$ nahu wa Ta ${ }_{\uparrow} l a$ ) but rather it has a broad meaning and can take many forms in which the connection with the Divine is intended. Secondly it is not only a mental activity rather it is associated with physical activities as well, such as Salat (prayer) in Islam.

\section{Origin of meditation in Buddhism and Islam:}

If we talk from an Islamic perspective, the origin of meditation must have been started from the very first human being in the universe. When we talk about the origin of meditation before Buddha It is reported that it is hundreds of years old, but there is no record for the exact origin of meditation. We can find the earliest ancient recorded writings about meditation the in Indian old scriptures Vedas about 5,000 years ago. What is quite clear is that meditational practices have always been an important part of Indian intellectual and social landscape. So it comes as no surprise that Buddha who was originally a Hindu also took up meditation and probably introduced a new way of meditation. He then learned how to quiet and soothe his inner thoughts and develop a strong form of concentration. Buddhism began to spread and practices of meditation eventually made its way to China, Japan, Tibet, Sri Lanka, etc. ${ }^{\text {xxviii }}$

Meditation has been always central to Buddhism despite its various sects. Its importance lies in the fact that it is fundamental to the ultimate goal of Buddhism that is gaining 
enlightenment. Buddha is known to have attained enlightenment as a result of long time of meditation sitting under a Bodhi tree present in India. The philosophy behind the purpose of meditation in Buddhism is to realize that suffering and impermanence are inherent in everything in the world and that there is no nothing as a permanent self or soul. To realize this reality one has to meditate to gain and acquire true vision into the true nature of things to end suffering. One ought to attain a relaxed and a unified mind through meditation and to be aware of the bitter reality of this mortal world.

As far Mur $q$ qabah in Islam is concerned, it also occupies a central and crucial position in Islam. Mur $q$ qabah in Islam means to always feel the presence of Allah and to realize that he is always present with us and watch over us. When this realization accompanies any Muslim all the time, he would always act perfectly in accordance with Islamic injunctions as if he/she is seeing Allah and that is the state of $I_{\left.F^{S}\right\rceil} n$ (perfection) in Islam. To meditate in Islam means to be in a state of $I_{F S}{ }^{n}$. This is evident from the following $\mathrm{Fad}^{\perp}$ th when $\mathrm{Jibr}^{\lrcorner}{ }^{1}$ asked the Prophet (pbuh) about $I_{\left.F^{S}\right\rceil} n$, the Prophet (pbuh) replied: $I_{\left.F^{S}\right\rceil} n$ is "to worship Allah as if you are seeing Him, if you cannot see Him, indeed He sees you".

I have tried to analyze some of the major concepts in both the traditions to clearly depict how far they resemble or are different from each other in their journey of meditation.

\section{The Concept of God in Buddhism and Islam:}

a. Concept of God in Buddhism, or is nirvana God?

As I mentioned in my abstract that nirvana is the only ideal worth striving for as far as a Buddhist monk is concerned. The question that came into my mind while dealing with the concept of nirvana is that "is nirvana God or like God"?

The most common thought about Buddhism is that it has no concept of God as a Supreme Being simply because Buddha never talked about the concept of God but always remained silent. He always adopted a neutral kind of attitude towards the metaphysical questions about the existence of God, creation of the world, what will happen after death, etc. Buddha explained the reasons for not answering the metaphysical questions by using a metaphor of a wounded person who was shot by a poisoned arrow. He said that the wounded person was in need to pull out the arrow that injured him to save his life, but questions like where the arrow came from or who shot it were not important to ask or to get to know about. ${ }^{\text {xix }}$ 
There can be multiple reasons for not answering these questions. Reasons can be that he didn't want to confuse his disciples by these issues, or that he couldn't find the right words to explain it and found it above the human capacity to understand, or that he was more concerned with human enlightenment so that he didn't bother to talk about such issues. These are my own assumptions that can be either right or wrong. Whatsoever the reasons were, according to my understanding silence does not necessarily mean denial. He didn't deny the existence of God.

However, Buddha always spoke of nirvana as the highest happiness, a state of bliss, perfect peace, permanent, stable, immovable, unborn, deathless, ageless, supreme reality and incomprehensible peace etc.

Is there any difference between these attributes of nirvana when compared to the idea of God in other religions? If the answer is no we may think of nirvana as an adjustment of the place of God in Buddhism or perhaps it means union and annihilation in God.

A similar conclusion is given by Huston Smith in his book The World Religions. He tried to deal with this issue by giving a very reasonable answer.

The first meaning given by him is that of a Personal Being who created the universe by a planned design. If we consider this meaning we cannot fit nirvana in it because Buddha did not consider nirvana to be personal. According to Buddhist tradition personality requires definition and nirvana is above it, meaning thereby that we cannot define nirvana. ${ }^{\mathrm{xxx}}$ The second meaning of God given by Huston Smith is that of the Godhead. ${ }^{\mathrm{xxxi}}$ The concept of Godhead is best understood by the apophatic theology of Meister Eckhart, one of the Christian famous mystics of the middle Ages. Apophatic is a Greek term for a supernatural way of reflecting on the ultimate reality. "It is a way of knowing God by not knowing". It means to use a negative form of mystical language to express the ultimate reality. ${ }^{\text {xxxii }}$ Meister Eckhart differentiates between the concept of God and the Godhead by working and not-working, which means God works but the Godhead does no work; there is nothing for it to do, there is no activity in it. ${ }^{\text {xxiii }}$

When Meister Eckhart speaks about God, he means the God of metaphysics, God that created everything and bring all creatures into being. And when he speaks of the Godhead, he means the God that is beyond our comprehension and beyond grasp of metaphysics that 
cannot be grasped. Godhead for him is the God of mysticism and that is the true God that cannot be grasped by any type of conceptualizations. He also asserts that Godhead is beyond any designation or name that the mind could ever apply to Him. ${ }^{\text {xxiv }}$

What I understand from Eckharts statement is that we can apply both the negative and the positive attributes to God that is the creator of creatures always active. On the other hand Godhead is a supernatural being to whom positive attributes cannot be applied because it is above the human perception and human language. We can describe the idea of Godhead only in negative terms that shows it is inconceivable and indefinable entity. Similarly nirvana is expressed in negative terms that do not actually convey it infinite content. It is understood only through experience. This is the reason that led Huston Smith to fit Nirvana under the concept of the Godhead.

Edward Conze said the attributes of nirvana can be applied to the idea of Godhead as well. In this sense nirvana is close to the concept of God as Godhead. ${ }^{\mathrm{xxxy}}$

In this sense we can conclude that meditation is not only practices to overcome the sufferings of life but it has a higher goal beyond that is the attainment of nirvana which can have a superficial meaning as mentioned above.

b. Concept of God in Islam:

A firm belief in Allah and the oneness of Allah is of fundamental importance of the Islamic belief. It is the first condition of faith. Nearness of Allah is the goal behind mur 7 qabah in Sufism.

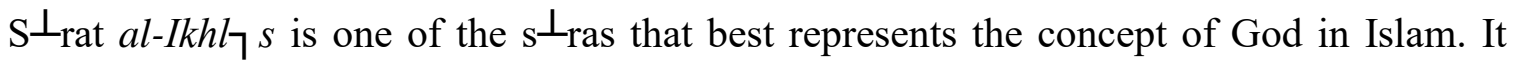

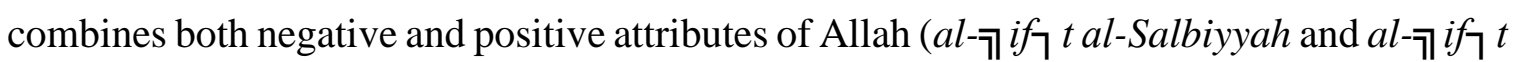
$a l-\vdash_{j}$ biyyah). God in Islam is known through these two attributes. $A l-\eta i f_{\rceil} t a l-\vdash_{j}$ biyyah affirms what Allah is and al-7if t $_{7}$ al-Salbiyyah negates what Allah is not. ${ }^{\text {xxxvi }}$

$\mathrm{S} \perp_{\text {rat al-Ikhl }} \mathrm{s}$ reads as follows:

Allah says:

"Say: He is Allah the One and Only; the Eternal, the Absolute; He begets not, nor is $\mathrm{He}$ begotten; and none is like Him". 
The first verse affirms the oneness of Allah. That Allah is one, and has no partners. Nobody is like Allah nor shares in His essence, attributes, or actions. He is the sole Creator of the entire universe. Everything is created by Allah's command. Every being that came into existence after it did not previously exist. ${ }^{\text {xxvii }}$

The second verse affirms that Allah is eternal, which means that he does not die, nor is he brought into this life through birth. Allah the Eternal has no beginning and He will never succumb or come to an end. ${ }^{\text {xxviii }}$

The third verse in a way of negation makes it explicitly clear that Allah does not beget any children, therefore having no sons or daughters. ${ }^{\mathrm{xxxix}}$

Finally the $s \perp_{\text {rah }}$ ends up by saying that Allah is above all, that he is unlike any of us. There is no one like Allah, and it is impossible to imagine or perceive Him. Allah is not measured and does not fall under the laws of creation because He is the sole Creator of the whole universe. He is not limited by direction or distance. Allah is eternal. ${ }^{\mathrm{xl}} \mathrm{He}$ not only created time and space, but $\mathrm{He}$ is beyond them. We cannot explain Allah in words. He is above the human language. ${ }^{\text {xli }}$

I would end up this portion by the following verse that shows that Allah Almighty is inconceivable simply great. Allah says:

"There is nothing like Him, and He is the One all Hearer and all Seer"xlii

\section{Salvation in Buddhism and Islam:}

a. Concept of salvation in Buddhism:

According to the Buddha, life is suffering and that every living being is subjected to

suffering. The only way to bring an end to suffering is to accept the four noble truths sliii $^{\text {xii }}$ and to follow the Noble Eightfold Path implementing each one of them. The Noble Eightfold path consist of the eight practices of self-training. They can be categorized into three categories: morality (sila), meditation (samadhi) and wisdom (panna). 
Although Sangha ${ }^{\text {xliv }}$ in Buddhism is responsible for teaching the dharma ${ }^{x l v}$ and conveying the message of Buddha, salvation in Buddhism according to my understanding is basically an individual salvation which is attained through self-help. There is no divine or human help from outside; rather, everyone meditates for his/her own benefit. The Sangha only directs the people towards the way of salvation.

It is important to mention here that the one who follows and implements this path of enlightenment has to depend on totally on his/her inner strength and effort.

Buddha says:

"So, Ananda, you must be lamps unto yourselves. Rely on yourselves, and do not rely on external help. Hold firm to the truth as a lamp and a refuge, and do not look for refuge to anything besides yourselves. A brother becomes his own lamp and refuge by continually looking on his body, feelings, perceptions, moods, and ideas in such a manner that he conquers the cravings and depressions of ordinary men and is always strenuous, selfpossessed, and collected in mind. Whoever among my disciples does this, either now or when I am dead, if he is anxious to learn, will reach the summit". xlvi

In the above mentioned saying Buddha declares that only those would attain enlightenment who strives and works hard to get rid all kinds of engagements that lead to suffereings and hinders enlightenment and awakening is possible only for those who rely on their own efforts.

b. Concept of salvation in Islam:

Although every Muslim is individually responsible for his/her deeds, salvation in Islam unlike Buddhism is not possible without the help of Allah and His will. I have discussed this topic under three issues:

- Individual responsibility

- Collective responsibility

- Divine help and Intercession of Prophet Muhammad $\left(S_{7}\right.$ alla $\left.A l l\right\rceil h u$ 'Alayhi Wa Sallam) 


\section{Individual responsibility:}

Allah says:

"Whoever does right, he does right only for the benefit of his own self. And whoever does wrong or goes astray, then that wrong and goes to his own loss. No one is loaded with another's burden..."xlvii

Allah says: "Nay! Man is evidence against himself. Though he puts forth his excuses."xlviii "...surely the hearing, sight and the heart, all of these, shall be questioned about their deeds." $x$ lix

The Holy Qur' $7 \mathrm{n}$ ver clearly views and explains the principle of individual responsibility, where everyone is solely responsible for his/her actions. Allah shows us the both paths of good and evil and leaves that for the person to choose reminding him/her of the final destination and the result of that particular path one choose.

\section{Collective responsibility:}

After the individual responsibility comes the collective ones. Muslims are obliged to help others in reaching the truth by directing others towards the right path. I think the devotional attitude is more emphasized in Islam. The concept of (al-amr bi'l-ma ' $r \perp_{f}$ wa al-nah ${ }^{\perp}$ 'an al-munkar) is made an obligation.

The Holy Qur' $\eta^{\mathrm{n}}$ declares (al-amr bi'l-ma' $r \perp_{f} w a$ al-nah ${ }^{\lrcorner}$'an al-munkar) as an obligation of Muslim Ummah:

"You are the best nation that has been raised for people. Directing towards good and forbidding what is wrong and you believe in Allah."1

"Let there arise out of you a band of people inviting all towards that is good, instructing towards right, and forbidding from what is wrong. They are the one who are successful."li The Prophet $\mathrm{Mu}$ Fammad ( $S_{\rceil}$alla $A \mathrm{All}_{\rceil}$hu 'Alayhi Wa Sallam) says:

"Whoever among you sees an evil; he/she should change it with his/her hand. If he/she is unable to do that, then he/she should change it with his/her tongue. If he/she is unable to do that either, then he/she should try to change it with his/her heart and that is the weakest level of faith $(\vdash-m\rceil n)$." lii 
The concept of (al-amr bi'l-ma' $r \perp_{f}$ wa al-nah ${ }^{\perp}$ 'an al-munkar) is the most common activity in all social settings; especially the Muslim Sufis played a major role throughout the history in directing the people towards the right path (the spiritual path).

Divine help and Intercession of Prophet Mu Fammad ( $S_{7}$ alla $\mathrm{All}_{\rceil} h u$ 'Alayhi $\mathrm{Wa}$ Sallam):

Although Muslims are commanded to lead a straight life according to Islamic injunctions and are always reminded of the reward or punishment in Hereafter but their salvation lies in the hands of Allah only and $\mathrm{He}$ is going to dispense it the way He sees it appropriate. No matter how good Muslims we are, we cannot enter paradise without the mercy of Allah. Good deeds are only means to enter paradise but mercy and grace of Allah are the sole reasons of salvation in hereafter. Muslims should always seek the Divine help by obeying Allah and repenting from sins and in returns He guides (hid $\rceil$ yah) and showers His mercy; no doubt Allah is all Merciful.

Allah says:

"And those who struggle in our path (cause), We will guide them towards our path for sure: For verily Allah is with those who do right."liii

Allah Almighty has given the Prophet Mu fammad ( $\mathrm{S}_{7}$ alla All 7 hu 'Alayhi Wa Sallam) the honor of intercession ${ }^{\text {liv }}$ of his Ummah on the Day of Judgment. Muslims also pray to Allah after every $\left(A d h_{\rceil} n\right)$ to bless them with the intercession of the Prophet. But again the intercession of the Prophet is not possible without the permission of Allah.

Allah says:

"Indeed! (O Muhammad), you cannot guide and give hidaya to those who you love, but Allah guides whom He wills."lv

The Holy Prophet says, "My intercession is for those who sincerely bore witness that nobody is worthy of worship but Allah- while his heart confirms what his tongue utters"lvi $\mathrm{Ab}^{\perp}$ Hurayra $\left(R a \Gamma^{\perp} A l l_{\rceil} h u\right.$ 'Anhu) said that the Holy Prophet said, "I will be the leader of the children of Adam on the day of resurrection, and the first one for whom the earth will be opened, the first Intercessor and the first whose intercession will be accepted". lvii

\section{The concept of asceticism in Buddhism and Islam:}

a. Asceticism in Buddhism: 
Every Buddhist has to lead a purely ascetic life in order to become a monk and join the monastery. To strictly follow the path of enlightenment in Buddhism a monk has to leave everything and adopt a simple life following the entire moral rules. Monks and nuns are required to beg instead of working, cannot marry or have a family, cannot participate in politics and have to get rid of all social engagements because according to Buddha they are a hurdle in the path of enlightenment. They are therefore dependent on their community, who supports them in their quest for enlightenment.

b. Asceticism in Islam:

Asceticism is not allowed in Islam. The Prophet Mu Fammad ( $\mathrm{S}_{7}$ alla All $h$ hu 'Alayhi Wa Sallam) says:

"There is no monkhood in Islam". lviii

Islam does not allow priesthood as a profession as it also discourages monasticism. To remember Allah and to meditate on Him does not require from a Muslim believer to leave his social life and lead an isolated life. Islam presents the life of Prophet $\mathrm{Mu}$ Fammad ( $\mathrm{S}_{\rceil}$alla $\mathrm{All}_{\rceil}$hu 'Alayhi Wa Sallam) as an example for the whole mankind.

It is evident from the above mentioned teachings of Islam that Islam teaches that a human being is the vicegerent of God on earth and has responsibilities at all levels whether it's an individual responsibility, to families or society as a whole. By maintaining a unique balance between all these responsibilities, Islam maintains a balance in all directions.

Allah says: "Thus we have made of you a balanced nation, so that you will be witness over the mankind and the Messenger will be a witness over yourselves." "lix

Narrated 'Abd All $\eta_{\rceil}$ibn 'Amr ibn al-' ‘ Wa Sallam) said to me: "O 'Abd All $\rceil$ h! I have been informed that you fast daily during the day and offer prayers every night?" 'Abd All $\rceil$ h replied, "Yes, O Allah's Prophet! The

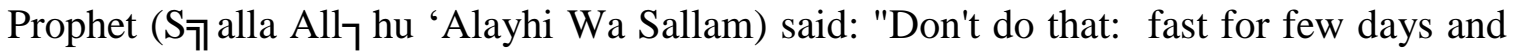
then give it up for few days, offer your prayers but you should also sleep at night, because your body had a right on you, and your wife has a right on you, and your guest has a right on you..."1x 


\section{Chanting Mantras in Buddhist meditation and repetition of dhikr in $\operatorname{mur}_{7}$ qabah:}

There are certain religious words and phrases known as mantra repeated in Buddhism as a part of meditation. Similarly dhikr is a form of prayer or Divine names that are repeated in the mur 7 qabah in Islam.

Mantras are sacred words or phrases that are repeated in Buddhist meditation. They contain the spiritual teachings given by Gautama Buddha 2500 years ago. ${ }^{\text {lxi }}$ Buddha says:

"If you want to eradicate worldly desires and to put on an end to suffering, make a circular string of 108 beads from the seeds of the bodhi tree". .xii

2500 years ago Buddha taught a short mantra of the three jewels (Buddha, dharma and sangha). ${ }^{\text {lxiii }}$ A rosary consisting of 108 beads is usually used for the recitation of mantras. The rosary used is known as mala in Buddhism. ${ }^{\text {lxiv }}$ The aim behind chanting of mantras is to purify one's negative emotions, to protect one from the negative influences and illnesses to get rid of all kinds of sufferings. ${ }^{\text {.xv }}$

Some mantras can be freely given or shared, but some mantras should only be learned from a trained teacher. ${ }^{\text {lxvi }}$

Buddhists are commanded to recite daily some verses from Vandan 7 . Vandan 7 is a compilation of Buddhist recitals that contain $\mathrm{P}_{\rceil}$li devotional hymns and chanting. ${ }^{\text {lxvii }}$ The $\mathrm{P}_{\rceil}$li sacred chanting's include recitations for taking shelter in the Triple Gem (Buddha, Dhamma and Sa Fgha), recitation of the Five Precepts, verses of symbolic offerings of lights, incense and flowers to the Buddha and the Bodhi Tree. The intention behind these chanting's also to transfer merits to celestial beings and the deceased relatives. In addition to the $\mathrm{P}_{7}$ li devotional hymns selected forty six verses from the Dhammapada are also recited. $^{\text {1xviii }}$

As far as dhikr in the mur 7 qabah is concerned:

Either silent or loud dhikr is preferred in the Islamic tradition of mur 7 qabah. For example: silent dhikr is the most common dhikr that is widely practiced in the Naqshband ${ }^{\text {lxix }}$ tradition. And the most common is that of the dhikr of affirmation and negation (naf ${ }^{\lrcorner} w a$ $i t h b_{\rceil} t$ ): $l_{\rceil}$ill $l_{\rceil}$ha illa $A l l_{\rceil} h$. Like the Buddhist tradition here also there is a need of a guidance of an expert teacher (shaykh) to follow the special method of this dhikr. 
Apart from the dhikr of affirmation and negation there are many individual wa $\mathrm{E}_{7}$ 'if that are daily recited in morning and evening individually. These are the masn $\perp_{n}$ prayers taught by the Prophet ( $S_{\rceil}$alla $\left.A l l\right\rceil h u$ 'Alayhi Wa Sallam).

\section{Psychological and Physical Effects of meditation in Buddhism and the $\operatorname{mur}_{7}$ qabah in Islam:}

The psychological and physical effects of meditation in Buddhism and mur 7 qabah in Islam are quite similar.

Psychological and physical effects of meditation in Buddhism:

Modern western clinical studies have proved that Buddhist meditation is good for health and mind as a tool for healing. Some of the benefits are as under:

Self-improvement

Stress Reduction

Pain management

Increased productivity ${ }^{1 \mathrm{xx}}$

Thus, concentration exercises create better efficiency at work because through concentration the meditator is able to have a unified calm mind. For example breathing meditation creates physical awareness of the feeling of the breath. It makes it to work in a better way than usual and it leads to a better breathing due to improved function of lungs and a healthy functioning of heart. The more the breath is deepened, the quieter the mind becomes with a refreshing effect on body. Some research also proved that meditation may also help those who suffer from insomnia (sleeping disorders). ${ }^{\text {lxxi }}$

Meditation through visualization can help in healing, pain-control. Such people are also capable of reaching the truth quickly as compared to common people. Ixxii

Buddhist meditation also helps in reducing blood pressure and cholesterol, which can help in the better functioning of heart. It also suspends conscious and ego-related thinking. It also expands the vision and understanding of the meditator and eventually transforms him or her from an ordinary to a sagely or enlightened person. ${ }^{\text {.xxiii }}$

According to a research study of Buddhist meditation led by some of the neuroscientists in the west in 1970s that the power of meditation also help in reducing stress and calming the negative emotions, it also improves things like immune function as well. In the Stress 
Reduction Clinic at the University of Massachusetts Medical School in 1979, about 16,000 patients had been treated by Buddhist meditation and more than 2,000 health professionals were taught the techniques of "mindfulness meditation," as a way of reducing stress. It was also reported that cancer patients practicing meditation had significantly better emotional outlooks than others; and not only that meditation relieved symptoms in patients with anxiety and chronic pain but also that the benefits lasted up to four years after training. ${ }^{\text {Ixxiv }}$

\section{Physical and psychological effects of mur $_{\rceil}$qabah in Islam:}

There are physical as well as psychological benefits of the mur 7 qabah

Physical Benefits of practicing mur 7 qabah are:

It helps in balancing the high blood pressure as it reduces work load of the heart.

It lowers cholesterol levels.

It improves flow of air to the lungs that results in easier breathing. This has been very helpful to asthma patients. ${ }^{\mathrm{l} x \mathrm{x}}$

All this requires strong evidence.

Psychological Benefits are:

Practice of mur 7 qabah sharpens the mind; it becomes more active with improved right reasoning, and higher IQ. It also improves learning ability and memory.

It decreases anxiety. ${ }^{\text {lxxvi }}$

It decreases depression.

It decreases the anger of bad tempered people.

It increases feelings of liveliness and energy.

It also helps in increasing happiness.

It also Increases emotional stability. ${ }^{1 x x v i i}$

\section{Conclusion:}

Islam and Buddhism are both universal in approach. They both teach moderation and a middle way to approach life. They both stress on spiritually in a very unique way. When it comes to Islam and Buddhism, spirituality and spiritual experiences are highly emphasized on to purify our bodies and souls. Both the religions emphasize on moral values before 
any religious commitment that paves the way for a true and better life style now and hereafter.

ii See Christmas Humphreys, A Popular Dictionary of Buddhism (London: The Buddhist Society, 1994), p.101.

iii See Edward A. Irons, "Jh $\rceil_{n a}$ ". In Encyclopedia of World Religions: Encyclopedia of Buddhism, ed. J. Gordon Melton (New York: Edward A. Irons, 2008). pp.161, 203.

iv See A Popular Dictionary of Buddhism, p.58.

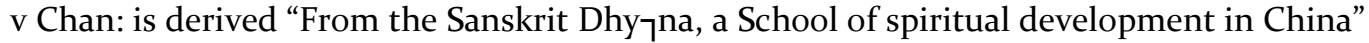

(mediation). See Popular Dictionary of Buddhism, p.42.

vi Zen literally: "is the Japanese equivalent of the Chinese Ch'an or Ch'an-na, derived from the Sk. Dhyāna, translated as "silent meditation". It usually refers to the practice of sitting meditation "zazen". It is the meditational school of Buddhism developed in Japan. See Popular Dictionary of Buddhism, p. 266.

Zen Buddhism stresses the personal experience of enlightenment based on a simple life lived close to nature and upon methods of meditation which avoid complicated rituals and abstruse thought. See Encyclopedia of World Religions: Encyclopedia of Buddhism, p. 592.

vii See Gardner James, Faiths of The World: A Dictionary of all Religions and Religious Sects, their Doctrines, Rites, Ceremonies and Customs (Delhi: Manas Publication, 1860), vol.1, p.711.

viii See Encyclopedia of World Religions: Encyclopedia of Buddhism, p.418.

ix Right effort (Samm $\mathrm{V}_{ך} \mathrm{~V}_{7} \mathrm{ma}$ ) "is the sixth step on the Noble Eightfold Path. The Efforts are described as that to destroy such evils as has arisen in the mind, to prevent any more arising; to produce such good as has not yet arisen in the mind, and to increase the good which has arisen. Together these may be described as developing a right effort". See A Popular Dictionary of Buddhism, p.251.

x Right mindfulness: "the seventh step on the Eightfold Path implies constant control of the thoughts". See A Popular Dictionary of Buddhism, p. 139.

It "indicates the individual's awareness of the body, sensations, the mind, and all thoughts that arise in the mind. The development of right mindfulness requires some sort of meditation". See Encyclopedia of World Religions: Encyclopedia of Buddhism, p.418.

xi Right concentration: "Is the last step on the Noble Eightfold Path and a prelude to Nirv 7 a." See A Popular Dictionary of Buddhism, p.188.

xii See Encyclopedia of World Religions: Encyclopedia of Buddhism, p.44.

xiii Vipassan 7 : Literally: "Insight or intuitive vision". It is a "system of meditation practiced in the

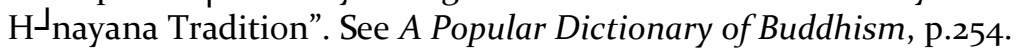

Through Vipassan 7 meditation the meditator perceives awareness of reality. It is usually gained through a long process of concentration and meditational practices. The ultimate goal and result of insight meditation is to see into the impermanence ( annic $_{7}$ ), unsatisfactory nature (dukkh 7 ), and lack of self ( $\mathrm{an}_{\rceil} \mathrm{tman}$ ) in all things. See Rosemary Goring, ed., The Wordsworth Dictionary of Beliefs and Religion (Edinburgh: W\&R Chambers Ltd, 1992) p.553.

xiv See Ibn Man $\bigsqcup_{\mathrm{r}}$ al-Ifr $\left.\lrcorner_{\mathrm{q}}\right\lrcorner$, Lis $\eta^{n}$ al-'Arab (Beirut: $\mathrm{D}_{7^{\mathrm{r}}}^{\mathrm{r}} \eta_{\eta}$ dir, n.d.), vol.1, p.424.

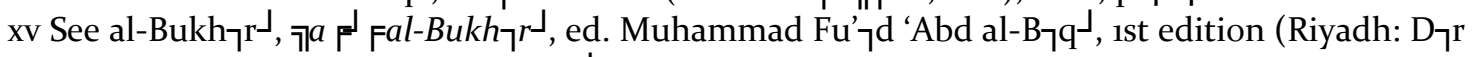
al-Sal 7 m, 1419), Kitךb al-Man 7 qib, ad ${ }^{-}{ }_{\text {th no. }} 3713$.

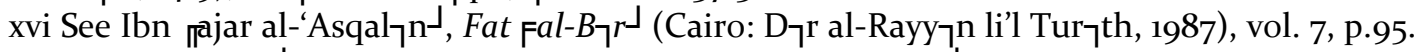

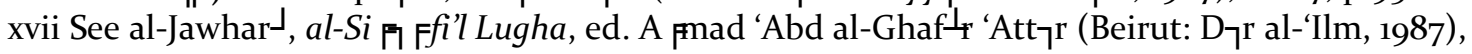
vol.1, p.264.

xviii Al-Qur' $\urcorner^{\mathrm{n}, 1:} 4$. 


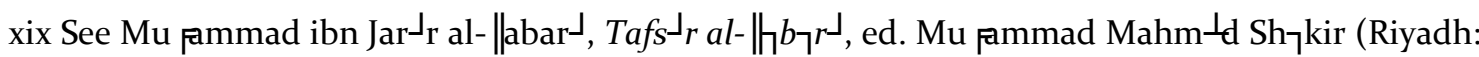
Mu'assasat al-Ris 7 la, 2000), vol. 20, p. 304.

xx Al-Qur' 7 n 20: 94.

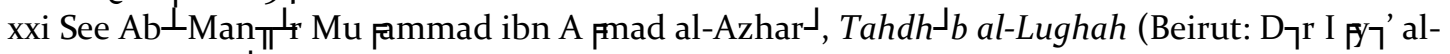
Tur $7^{\text {th }}$ al-'Arab', 2001), vol.3, p.218.

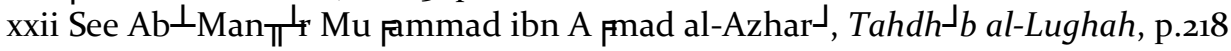

xxiii Al-Qur'ךn 11: 93.

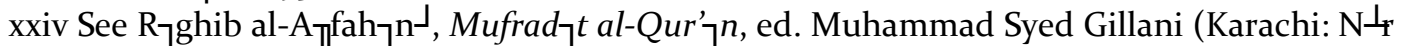
Mu ammad Kit 7 bcha, n.d.), p.2o1.

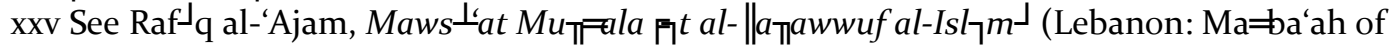
Lebanon, 1999), p.914.

xxvi See al-Qushair $\lrcorner$, al-Ris $\rceil^{l a h}$ al-Qushairiyya (Cairo: ${ }^{1}{ }^{\mathrm{r}}$ al-Tib ${ }^{\prime}$ 'ah al-Amirah, 1870), p.102.

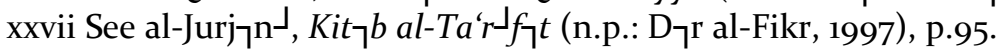

xxviii See Wilson, P. "Origin of Meditation", EzineArticles, 3 Feb. 2008.

$<$ http://ezinearticles.com/?Origin-of-Meditation\&id=964808>.(accessed on 15 Feb. 2010) xxix See Kwangsoo Park, "An Analysis of the Buddha's Paradoxical Silence: Neither the Positive nor Nihilistic View" in International Journal of Buddhist Thought \& Culture (Korea: International Association for Buddhist Thought \& Culture, February 2006), vol.6, pp.243-264. xxx See Huston Smith, The World Religions (Lahore: Suhail Academy, 2002), p.114, 115. xxxi Ibid., p. 115.

xxxii See Wayne Teasdale, The Mystic Heart: Discovering a Universal Spirituality in the Worlds Religion's (n.p.: New World Library, 1999), p. 59.

xxxiii See Richard Woods, OP, Eckharts way (Minnesota: The Liturgical Press, 1990), p. 47. xxxiv See Eckharts way, p. 96.

xxxv See Edward Conze, Buddhism: Its Essence and Development (New York: Harper \& Row, 1951), p. 105.

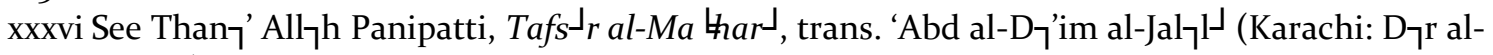
Ish ${ }^{\prime}$ 'at, 1999), vol. 12, p. 378.

xxxvii See Ibn Taimiyya, Tafs $\left.\lrcorner_{r} S\right\lrcorner_{r a t}$ al $I k h l_{\rceil} s$ (Sahiwal: Ma=ba'ah Mu fmadiyya, 2004), p. 22. xxxviii Ibid., p. 7, 8.

xxxix Ibid., p. 26.

xl See Tafsir al Ma thar , p. 381.

xli See Tafsir al Ma thar , p. 381.

xlii Al-Qur' $\rceil^{\mathrm{n}}$ 42: 11.

xliii Four Noble Truths: "the basic truths of Buddhism, as set by the Buddha in his first sermon". They are: dukkh ${ }_{\rceil}$(suffering), samyudana (the cause of suffering), nirodha (the elimination of desire) and magga (the way to the elimination of desire that is the Noble Eight Fold Path). See $A$ Popular Dictionary of Buddhism, p.79.

xliv Sangha: "An Assembly. The monastic order founded by the Buddha, the members of which are called Bhikkhus." See A Popular Dictionary of Buddhism, p.194.

${ }^{x l v}$ Dharma: "A doctrine. Any teaching set forth as a formulated system; the guiding principles accepted or followed by a Buddhist; the Teachings of the Buddha". See A Popular Dictionary of Buddhism, p.55.

xlvi See Digha Nikaya 2, pp.99-100.

xlvii See Qur' $7^{n}$ 41: 46

xlviii See Qur' ${ }^{\mathrm{n}}$ 75: 18

xlix See Qur' $7^{\mathrm{n}}$ 17:36

1 See Qur' $\rceil^{\text {n 3:110. }}$

li See Qur' 7 n: 104.

lii See $7^{a} F^{\prime}$ Fuslim, Book of Belief, $\mathrm{md}^{\lrcorner}{ }^{\mathrm{t}}$ th no. 49 . 
liii See Qur'ךn 29: 69.

liv Intercession: Definition - To plead in favour of another, especially a prayer or petition to Allah on behalf of another. See Abu al Fa ४, $M^{\lrcorner} b a$ Fal' Lughaat (Karahi: Qadeemi Kutab Khana, n.d), p.

439 .

lv See Qur' 'n 28: 56.

lvi See $\eta^{a} \digamma^{\prime}$ Fal-Bukh$h^{r}$, book of al-'Ilm, ad ${ }^{\lrcorner}$th no. 99.

lvii See $7 a F_{F}$ Muslim, ad $\lrcorner_{\text {th no. } 2278 .}$

lviii See Ab ${ }^{\lrcorner}$Shayba, Muך annaf $A b^{\lrcorner}$Shayba al-Karkh ${ }^{\lrcorner}$(Beir $\perp_{\mathrm{t}}$ : $\mathrm{D}_{7}$ r al-Fikr, n.d.), vol. 3, p. 270.

lix See Qur' $\rceil^{\text {n 2: } 143 .}$

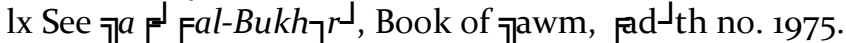

lxi See Bruce Conway, Mantra Mala Manual (n.p.: Dharma Works, 2001), p. 7.

lxii See Quoted by Erik Walker Wikstrom, Simply Pray: A Modern Spiritual Practice to Deepen your

Life (U.S.A: Skinner House Books, 2005), p. 60.

lxiii See Mantra Mala Manual, p. 7.

lxiv See Simply Pray: A Modern Spiritual Practice to Deepen your Life, p. 57.

lxv See Mantra Mala Manual, p. 7.

lxvi See Mantra Mala Manual, p. 7.

lxvii See Elgiriye Indaratana Maha Thera, Vandan $\rceil$ : The Album of $P_{\rceil} l i$ Devotional Chanting and Hymns (Malaysia: Mahindarama Dhamma Publication, 2002), p. xiii.

lxviii Ibid., p. ix.

lxix (Al-Naqshbandiyyah) is one of the major Sufi orders of Islam. The Naqshband $\lrcorner$ silsila traces its origin back to the Prophet Mu Fammad, See Hamid Algar, "The Naqshbandi Order: A Preliminary Survey of Its History and Significance" in Studia Islamica (Maisonneuve \& Larose, No.44, 1976), pp.127-128.

lxx See David Brazier, Zen Therapy (New York: John Wiley \& Sons, Inc, 1995), p.12.

lxxi See Zen Therapy, pp.45-52.

lxxii Ibid.

lxxiii See Marc Galanter, Cults Faith, Healing and Coercion (New York: Oxford University Press, 1999), p. 62.

lxxiv See Stephen S. Hall, “Is Buddhism Good for Your Health?” The New York Times, 2003, pp.1-4. http://query.nytimes.com/gst/fullpage.html?res=940CE1DB

lxxv See Nur Muhammad, Benefits of Meditation,

http://www.nurmuhammad.com/Meditation/BenefitsofMeditationnaqshbandisufiway.htm, accessed on $29 / 1 / 2010$.

lxxvi See http://nurmuhammad.com/Meditation/Mainmeditationmur $q$ qabah h.htm, accessed on 29/1/2010.

lxxvii Ibid. 